\title{
Proliferative compartment deregulation in the non-neoplastic colonic epithelium of familial adenomatous polyposis
}

Department of Surgery and Biological and Nutritional Sciences, The University of Newcastle upon Tyne $S$ J Mills

J C Mathers

Department of Pathology, Ninewells Hospital and Medical School, University of Dundee

P A Hall

Department of Pathology, Gloucestershire Royal Hospital, Gloucester N A Shepherd

\section{Departments of}

Pathology and

Surgery, Wansbeck

Hospital,

Northumberland

$S$ J Mills

A Hastings

A Gunn

Correspondence to: Ms S Mills, Department of Surgery, The University of Newcastle upon Tyne, Newcastle upon Tyne NE1 7RU.

Accepted for publication 24 June 1994

\begin{abstract}
Previous work has shown abnormalities in the proliferative activity of the colorectal mucosa in familial adenomatous polyposis (FAP). Some doubts remain about the validity of these findings because of difficulties in excluding adenomatous crypts, particularly in methods using tritiated thymidine, bromodeoxyuridine, and ornithine decarboxylase. The proliferative activity of the epithelium in colonic resections from 20 FAP patients was compared with that of age, sex, and site matched controls using a new monoclonal antibody MIB1 to assay the expression of Ki-67 antigen in routinely processed tissue. The labelling indices were very similar in the polyposis and control cases $(25.5(1.4) \%$ and $26.7(1.7) \%$ respectively) but analysis of the distribution of labelled cells showed a significant shift of the proliferative compartment towards the luminal surface in the FAP group. Specifically, the labelling index was lower in the basal fifth of the polyposis crypts and higher in the two fifths at the luminal surface. These results show that analysis of proliferative activity in FAP is now achievable in routine histological material and indicate deregulation of proliferative control in the FAP colonic crypt. This may form a useful diagnostic adjunct to standard clinical and molecular genetic techniques, particularly in view of the current interest in dietary and pharmacological intervention in sporadic colorectal carcinoma.

(Gut 1995; 36: 391-394)
\end{abstract}

Keywords: familial adenomatous polyposis, cell proliferation, $\mathrm{Ki}-67$ antigen, monoclonal antibody, MIB1, immunohistochemistry.

The risk of colonic neoplasia may be related to altered cellular proliferation within the mucosal crypts. ${ }^{1}$ In normal mucosa, basal stem cells undergo mitosis producing daughter cells that migrate up the crypt. Cells then exit the cell cycle and a state of terminal differentiation is reached. This results in a proliferative zone limited to the basal two thirds of the crypt. ${ }^{2}$ Expansion of this zone has been shown in a variety of preneoplastic conditions, most notably familial adenomatous polyposis (FAP). ${ }^{34}$ In addition, several studies have suggested a return to normal of crypt cell proliferation after treatment with agents thought to be antineoplastic. ${ }^{5} 6$ These changes may therefore identify both individuals at increased risk of colorectal cancer and an early effect of dietary or pharmacological agents aimed at preventing this.

The most widely used method of estimating crypt cell proliferation has required in vitro incubation of tissue with tritiated thymidine or bromodeoxyuridine. ${ }^{7}$ Studies using these techniques may be criticised as it is difficult to exclude microadenomas, and cell replication in culture may not be representative of cell behaviour in vivo. Direct immunohistochemical demonstration of a cell cycle related antigen became possible with a monoclonal antibody to the $\mathrm{Ki}-67$ antigen but this required fresh or snap frozen tissue. ${ }^{8}$ More recently, monoclonal antibodies have been raised to the proliferating cell nuclear antigen (PCNA) but this has a number of limitations as a marker of proliferation. ${ }^{9} 10$ Although direct mitosis counts are reliable and can be performed on three dimensional crypts, these are time consuming and are difficult to apply to paraffin embedded tissue. ${ }^{11}$ Large scale studies would be facilitated by a technique that could easily be performed as part of routine pathology services. A new monoclonal antibody, MIB1, has recently been raised to the $\mathrm{Ki}-67$ antigen. This can be shown in routinely processed, paraffin fixed tissue with microwave pretreatment and is a robust marker of proliferation. ${ }^{781012-14}$ Described here are the results of this monoclonal antibody applied to archival paraffin blocks in which adenomatous crypts can be confidently excluded.

\section{Methods}

Archival paraffin block specimens were collected for 20 FAP colectomy patients and for 20 age, sex, and site matched controls (Table I). The latter were right hemicolectomy specimens performed for ileal Crohn's disease in which the colon was histologically normal and in which there had never been clinically demonstrable colonic Crohn's disease. Sections $(4 \mu \mathrm{m})$ were cut and

TABLE I Characteristics of study and control groups from whom tissue blocks were obtained

\begin{tabular}{lll}
\hline & Controls & $\begin{array}{l}\text { Familial adenomatous } \\
\text { polyposis }\end{array}$ \\
\hline No & 20 & 20 \\
Age (y) (mean (range)) & $34 \cdot 7(16-63)$ & $34 \cdot 8(13-62)$ \\
Sex (M:F) & $10: 10$ & $10: 10$
\end{tabular}


TABLE II Total number of cells in crypt columns and number that stained positively for MIB1 in specimens from control and familial adenomatous polyposis (FAP) subjects

\begin{tabular}{|c|c|c|c|c|}
\hline & \multicolumn{2}{|l|}{ Controls } & \multicolumn{2}{|l|}{$F A P$} \\
\hline & $\begin{array}{l}\text { No of cells/ } \\
\text { hemicrypt }\end{array}$ & $\begin{array}{l}\text { No of } M I B 1 \\
\text { cells }\end{array}$ & $\begin{array}{l}\text { No of cells/ } \\
\text { hemicrypt }\end{array}$ & $\begin{array}{l}\text { No of } M I B 1 \\
\text { cells }\end{array}$ \\
\hline $\begin{array}{l}\text { Absolute counts (mean (SEM)) } \\
\text { Labelling index (mean (SEM)) }\end{array}$ & $85 \cdot 3(2 \cdot 4)$ & $\begin{array}{l}22 \cdot 7(1 \cdot 4) \\
26 \cdot 7(1 \cdot 7)\end{array}$ & $88 \cdot 1(2 \cdot 2)$ & $\begin{array}{l}22 \cdot 3(1 \cdot 3) \\
25 \cdot 5(1 \cdot 4)\end{array}$ \\
\hline
\end{tabular}

dewaxed, and endogenous peroxidase was blocked with $1 \% \mathrm{H}_{2} \mathrm{O}_{2}$ for 30 minutes. Before application of MIB1 primary antibody, the sections were microwaved in $0.01 \mathrm{M}$ citrate buffer, pH 6 at $850 \mathrm{~W}$ for 20 minutes. Immunoperoxidase detection was achieved with the avidin-biotin conjugate method followed by the diaminobenzidine with nickel cobalt enhancement reaction. Counter staining was performed with nuclear fast red. Negative controls were prepared with omission of the primary antibody.

All cell counting was performed by a single blinded observer (SJM) according to strict criteria. Care was taken to include only morphologically normal, perfectly longitudinally oriented crypts. In addition, crypts had to be complete as defined by the base abutting on the muscularis mucosae and the luminal surface junction with the neighbouring crypt being complete. The total number of cells in each hemicrypt was counted, divided by five and the number of stained cells in each fifth was determined. Any degree of nuclear staining was taken as positive. Every assessable crypt column in each section was counted, a mean of 14 crypt columns for each individual. Intraobserver variation was assessed by performing 10 recounts of the same two crypts on different occasions.

\section{Results}

In this study the age of the blocks varied from 1 to 11 years and all had been routinely formalin fixed and paraffin embedded. The quality of staining did not vary with the age of the blocks and was uniformly good and restricted to the cell nuclei. Assessment was simplified by the ease of discriminating between stained and unstained nuclei. The length of the crypt columns was very similar in the two groups (Table II) and it was straightforward to ensure the inclusion of morphologically normal crypts only, excluding even unicryptal adenomas. The mean coefficient of intraobserver variation was $4 \cdot 2 \%$. The mean total labelling indices were almost identical for both groups and were normally distributed (Table II).

TABLE III Distribution of labelled cells expressed as a percentage of all labelled cells found in each crypt compartment (CC) in controls and subjects with familial adenomatous polyposis (FAP)

\begin{tabular}{|c|c|c|c|c|c|}
\hline & $\begin{array}{l}\text { Crypt base } \\
\text { CC1 }\end{array}$ & $C C 2$ & $C C 3$ & $C C 4$ & $\begin{array}{l}\text { Crypt surface } \\
\text { CC5 }\end{array}$ \\
\hline $\begin{array}{l}\text { Control (mean (SEM)) } \\
\text { FAP (mean (SEM)) } \\
\text { p Value }\end{array}$ & $\begin{array}{c}38 \cdot 1(1 \cdot 5) \\
34 \cdot 1(1 \cdot 8) \\
0 \cdot 08\end{array}$ & $\begin{array}{c}39 \cdot 3(0 \cdot 8) \\
38 \cdot 2(0 \cdot 8) \\
0 \cdot 35\end{array}$ & $\begin{array}{c}19 \cdot 5(1 \cdot 1) \\
21 \cdot 8(1 \cdot 4) \\
0 \cdot 19\end{array}$ & $\begin{array}{l}3.0(0.8) \\
5.6(0.9) \\
0.04\end{array}$ & $\begin{array}{l}0.07(0.06) \\
0.5(0 \cdot 1) \\
0.005\end{array}$ \\
\hline
\end{tabular}

Despite considerable interindividual variation, the pattern of staining was consistent with labelled cells concentrated in the lower part of the crypts. Crypt columns were then divided into fifths as described above where crypt compartment 1 is the crypt base and crypt compartment 5 nearest the luminal surface. Analysis of the results using an unpaired Student's $t$ test showed that the labelling index was lower $(p=0.08)$ at the crypt base and higher $(p=0.005)$ at the crypt surface for the FAP colons (Table III and Figure).

\section{Discussion}

A number of authors have suggested that the proliferative compartment of the colonic epithelium from FAP patients is expanded compared with that of controls. ${ }^{13415-18}$ However, there have been some discordant reports, ${ }^{19} 20$ which may reflect the technical difficulties of the methods used. In this study a robust immunohistological method has been employed in good quality paraffin wax sections. This has demonstrated unequivocally a clear alteration of the proliferative compartment in the non-neoplastic epithelium of FAP colons.

The MIB1 antibody has been shown to stain comparably with Ki67 in fresh tissue and after microwave oven pretreatment, in paraffin sections. ${ }^{12} 21$ It is not known how microwave heating results in the unmasking of epitopes but it has been suggested that it changes the cross linking effect of formaldehyde fixation. ${ }^{22}$ Fixation times in excess of 24 hours can be corrected for by increasing the time in the microwave and 20 minutes has been suggested as an optimal heating time when fixation time is not controlled. ${ }^{23}$

The specificity of the $\mathrm{Ki}-67$ antigen for proliferating cells has been established, ${ }^{13}$ and expression correlates well with growth fraction. ${ }^{14}$ Although the role of this antigen in cellular proliferation has yet to be defined, considerable progress has been made recently

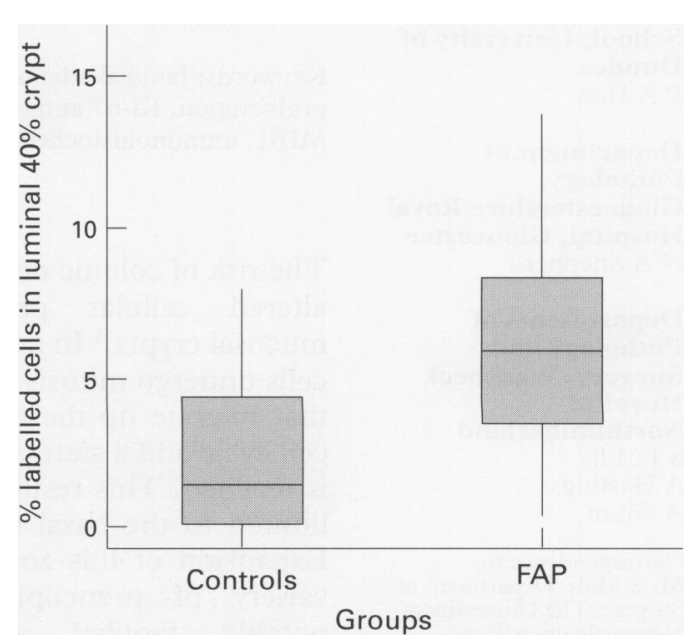

Proportion of labelled cells situated in the luminal $40 \%$ of the crypts (CC4+5) showing the $95 \%$ confidence interval for the median for the control and familial adenomatous polyposis (FAP) groups. 
in the characterisation of the antigen. After immunoblot analysis, Ki67 antibody recognised a double band of $\mathrm{Mr} 345$ and 395 $\mathrm{kD}$ in lysates of proliferating cells but not their non-proliferating counterparts. $^{24}$ Gerde's group went on to perform immunoscreening of a $\lambda \mathrm{gt} 11$ human cDNA expression library with Ki67 and obtained a 1095 base pair (bp) partial clone containing three repetitive sequences of 366 nucleotides. Once expressed, these regions were found to react specifically with Ki67 on SDS-PAGE suggesting that they code for the epitope recognised by the $\mathrm{Ki} 67$ antibody. ${ }^{25}$ Using this 1095 bp partial clone for chromosomal in situ hybridisation, the gene has been mapped to 10q25 (ter). ${ }^{26}$ Further characterisation of the gene has revealed 16 of the repetitive $366 \mathrm{bp}$ fragments containing highly conserved 62 bp regions. ${ }^{27}$ On the basis of this evidence it has been suggested that the function of the protein may be maintaining higher order structure for DNA during mitosis. ${ }^{28}$

In order to obtain age, sex, and site matched controls, it was necessary to use specimens removed for Crohn's disease. While these cannot be considered entirely ideal controls, none of these patients had colonic disease documented clinically or histopathologically. As this is a segmental disease, we believe that these specimens are the best obtainable controls for patients in the age range of the FAP patients.

Although there was considerable interindividual variation in the labelling indices, the pattern of distribution of labelling was consistent. In both groups, most labelled cells were in the lower three fifths of the crypt. Statistical analysis confirmed that there was a shift in the proliferative compartment towards the crypt surface in the FAP group. The labelling index in these patients was lower in the crypt base and higher at the crypt surface. This confirms previous in vitro work with tritiated thymidine, in which a similar pattern of change was described as a stage II abnormality (where stage I indicates an extension of the compartment towards the crypt surface and stage III an elevated overall labelling index). ${ }^{29}$ The cellular mechanisms regulating crypt cell renewal remain uncertain but this spatial shift in the proliferative compartment suggests deregulation of normal control mechanisms in FAP. Similar changes have been found using a variety of techniques in patients at high risk for colonic neoplasia. ${ }^{1630-33}$ It is possible that this change represents an early event in neoplastic transformation, although this view does not go unchallenged. ${ }^{19}$ An important application of this putative intermediate biomarker for neoplastic risk is in interventional studies. ${ }^{34}$ 35 With the current interest in dietary and pharmacological intervention in colorectal carcinoma, an immunohistochemical technique applicable to routinely processed tissue that may detect a preneoplastic abnormality has obvious attractions and the MIB1 based procedure seems promising in this regard.
We thank Dr Johannes Gerdes for his kind gift of the MIB1 primary antibody. We are also grateful to $\mathrm{Mr}$ Carl Hobbs and Mr Mike Reed who performed the immunostaining.

1 Lipkin M. Biomarkers of increased susceptibility to gastrointestinal cancer: New application to studies of cancer prevention in human subjects. Cancer Res 1988; 48: prevention

2 Wright NA, Alison M. The biology of epithelial cell populations. Vol 2. Oxford: Clarendon Press, 1984.

3 Deschner E, Lewis CM, Lipkin M. In vitro study of human rectal epithelial cells. I. Atypical zone of $\mathrm{H} 3$ thymidine incorporation in mucosa of multiple polyposis. $f$ Clin Invest 1963; 42 (12): 1922-8.

4 Lipkin M, Blattner WA, Gardner EJ, Burt RW, Lynch H, Deschner $\mathrm{E}$, et al. Classification and risk assessment of individuals with familial polyposis, Gardner's syndrome, and familial non-polyposis colon cancer from [3H]thymidine labelling patterns in colonic epithelial cells. Cancer Res 1984; 44: 4201-7.

5 Wargovich MJ, Isbell G, Shabot M, Winn R, Lanza F, Hochman L, et al. Calcium supplementation decreases rectal epithelial cell proliferation in subjects with sporadic rectal epithelial cell proliferation in subjects

6 Cahill RJ, O'Sullivan KR, Mathias PM, Beattie S, Hamilton $\mathrm{H}$, O'Morain C. Effects of vitamin antioxidant supplementation on cell kinetics of patients with adenomatous polyps. Gut 1993; 34: 963-7.

7 Hall PA, Levison DA. Review: Assessment of cell proliferation in histological material. F Clin Pathol 1990; 43: 184-92.

8 Gerdes J, Schwab U, Lemke H, Stein H. Production of a mouse monoclonal antibody reactive with a human nuclear antigen associated with cell proliferation. Int $\mathcal{f}$ nuclear antigen associa
Cancer 1983; 31: 13-20.

9 McCormick D, Hall PA. The complexities of proliferating cell nuclear antigen. Histopathology 1992; 21: 591-4.

10 McCormick D, Yu C, Hobbs C, Hall PA. The relevance of antibody concentration to the immunohistological quantitation of cell proliferation-associated antigens. Histopathology 1993; 22: 543-7.

11 Goodlad RA, Levi S, Lee CY, Mandir N, Hodgson H, Wright NA. Morphometry and cell proliferation in endoscopic biopsies: Evaluation of a technique. Gastroenterology 1991; 101 (5): 1235-41.

12 McCormick D, Chong H, Hobbs C, Datta C, Hall PA. Detection of the Ki67 antigen in fixed and wax embedded sections with the monoclonal antibody MIB1. sections with the monoclonal
Histopathology 1993; 22: 355-60.

13 Gerdes J, Lemke H, Baisch H, Wacker H-H, Schwab U, Stein $\mathrm{H}$. Cell cycle analysis of a cell proliferation associated human nuclear antigen defined by the monoclonal antibody Ki-67. F Immunol 1984; 133 (4): 1710-5.

14 Scott RJ, Hall PA, Haldane JS, Noorden SV, Price Y, Lane DP, et al. A comparison of immunohistochemical markers of cell proliferation with experimentally determined growth fraction. $\mathcal{F}$ Pathol 1991; 165: 173-8.

15 Potten CS, Kellett M, Rew DA, Roberts SA. Proliferation in human gastrointestinal epithelium using bromodeoxyuridine in vivo: data for different sites, proximity to a eoxyuridine in vivo: data for different sites, proxim
tumour, and polyposis coli. Gut 1992; 33: 524-9.

16 Lipkin M, Blattner WE, Fraumeni JF, Lynch HT, Deschner $\mathrm{E}$, Winawer $\mathrm{S}$. Tritiated thymidine labelling distribution as a marker for hereditary predisposition to colon cancer. Cancer Res 1983; 43: 1899-904.

17 Lipkin M. Phase 1 and phase 2 proliferative lesions of colonic epithelial cells in diseases leading to colonic cancer. Cancer 1974; 34: 878-88.

18 Lipkin M. Method for binary classification and risk assessment of individuals with familial polyposis based on 3HTdR labelling of epithelial cells in colonic crypts. Cell Tissue Kinet 1984; 17: 209-22.

19 Nakamura S, Kino I, Baba S. Cell kinetic analysis of background colonic mucosa of patients with intestinal neo-
plasms by ex vivo autoradiography. Gut 1988; 29: plasms by

20 Nakamura S, Kino I, Baba S. Nuclear DNA content of isolated crypts of background colonic mucosa from patients with familial adenomatous polyposis and sporadic colorectal cancer. Gut 1993; 34: 1240-4.

21 Cattoretti G, Becker MHG, Key G, Duchrow M, Schlüter $\mathrm{C}$, Galle J, et al. Monoclonal antibodies against recombinant parts of the Ki67 antigen (MIB1 and MIB3) detect proliferating cells in microwave processed formalin-fixed proliferating cells in microwave processed for

22 Shi SR, Key ME, Kalra KL. Antigen retrieval in formalinfixed, paraffin-embedded tissues: An enhancement fixed, paraffin-embedded tissues: An enhancement method for immunohistochemical staining based on
microwave oven heating of tissue section. $F$ Histochem Cytochem 1991; 39: 741.

23 Munakata $S$, Hendricks JB. Effect of fixation time and microwave oven heating time on retrieval of the $\mathrm{Ki}-67$ antigen from paraffin-embedded tissue. $f$ Histochem Cytochem 1993; 41 (8): 1241-6.

24 Gerdes J, Li L, Schlüter C, Duchrow M, Wohlenberg C, Gerlach $\mathrm{C}$, et al. Immunobiochemical and molecular biologic characterisation of the cell proliferation-associated nuclear antigen that is defined by monoclonal antibody Ki-67. Am f Pathol 1991; 138 (4) 867-73.

25 Gerdes J, Li L, Schlueter C, Duchrow M, Wohlenberg C Gerlach C, et al. Immunobiochemical and molecular biologic characterisation of the cell proliferation - associated nuclear antigen that is defined by monoclonal antibody Ki-67. Am F Pathol 1991; 138 (4): 867-73. 
26 Fonatsch C, Duchrow M, Rieder H, Schlüter C, Gerdes J. Assignment of the human $\mathrm{Ki}-67$ gene (MK167) to 10q25qter. Genomics 1991; 11: 476-7.

27 Schlüter $\mathrm{C}$, Duchrow $\mathrm{M}$, Wohlenberg $\mathrm{C}$, Becker MHG Key G, Flad H-D, et al. The cell proliferation-associated antigen of antibody $\mathrm{Ki}-67$ : A very large, ubiquitous nuclear protein with numerous repeated elements, representing a new kind of cell cycle-maintaining proteins. $f$ Cell Biol (in press).

28 Sawhey N, Hall PA. Ki67 - Structure, function, and new antibodies. $\mathcal{F}$ Pathol 1992; 168: 161-2.

29 Deschner EE. Early proliferative changes in gastrointestinal neoplasia. Am f Gastroenterol 1982; 77 (4): 207-11.

30 Paganelli GM, Biasco G, Santucci R, Brandi G, Lalli AA Paganelli GM, Biasco G, Santucci R, Brandi G, Lalli AA,
Miglioli M, et al. Rectal cell proliferation and colorectal cancer risk level in patients with nonfamilial adenomatou polyps of the large bowel. Cancer 1991; 68: 2451-4.

31 Gerdes H, Gillin JS, Zimbalist E, Urmacher C, Lipkin M Winawer SJ. Expansion of the epithelial cell proliferative compartment and frequency of adenomatous polyps in the colon correlate with the strength of family history of colorectal cancer. Cancer Res 1993; 53: 279-82.

32 Terpestra OT, van Blankenstein M, Dees J, Eilers GAM Abnormal pattern of cell proliferation in the entire colonic mucosa of patients with colon adenoma or cancer. Gastroenterology 1987; 92: 704-8.

33 Bleiberg $H$, Buyse $M$, Galand $P$. Cell kinetic indicators of premalignant stages of colorectal cancer. Cancer 1985; 56: 124-9.

34 Biasco G, Paganelli GM, Brandi G, Santucci R, Renga M Facchini A, et al. Rectal cell proliferation as an intermediate biomarker of risk of colorectal cancer. European fournal of Cancer Prevention 1993; 2 (suppl 2): 89-93.

35 Scalmati A, Lipkin M. Intermediate biomarkers of increased risk for colorectal cancer: Comparison of different methods of analysis and modifications by chemopreventive interventions. F Cell Biochem 1992; (suppl): 16G 65-71. 